\title{
O DEVIR NEGRO NA LITERATURA BRASILEIRA: NOTAS SOBRE A ORALIDADE EM LIMA BARRETO
}

\begin{abstract}
Jorge Augusto Silva*
"[..] as narrações caseiras dos pais, dos velhos parentes, dos amigos criados e agregados é que têm o poder de nos encher a alma do passado, de ligar-nos aos que foram e nos fazer compreender certas peculiaridades do lugar do nosso nascimento".

Lima Barreto

RESUMO: Neste texto buscamos traçar um breve panorama da tradição eurocêntrica das teorias da literatura e da crítica literária, no Brasil, ressaltando o aspecto central de sua formulação discursiva: o grafocentrismo. Tentaremos mostrar com as diversas concepções de crítica literária que circularam no campo das letras brasileiras eram grafocentricas, operando a partir de concepções de língua que não potencializam a apreensão do repertório cultural negro, na cultura brasileira. A partir desse cenário iremos expor como a escrita de Lima Barreto rasura essa engrenagem discursiva na literatura brasileira, operando um devir negro na linguagem literária nacional, através do uso do registro informal da língua no texto literário. Essa operação barretiana, não produz uma estetização da oralidade, mas propõe compreendê-la como base
\end{abstract} epistemológica de uma cultura negro-brasileira.

PALAVRAS-CHAVE: Literatura negra; Oralidade; Grafocentrismo; Lima Barreto.

\footnotetext{
* Docente do Instituto Federal do Maranhão. Colaborador na pós-graduação em educação e diversidade étnicorracial, na Universidade do Estado da Bahia (Uneb), campus VI. Doutorando em Literatura e Crítica da Cultura pela Universidade Federal da Bahia (Ufba).
} 


\section{A língua da teoria: grafocentrismo o e fantasma da unidade}

A crítica literária brasileira baseou-se, na construção de seu repertório crítico, em três concepções básicas de língua: a) na diacronia positivista; b) na sincronia estruturalista; c) na politização pós-estruturalista da língua. Nisso acompanhou o movimento geral das teorias da literatura em seus movimentos entre Europa e Estados Unidos. No Brasil, essas perspectivas redundaram numa abordagem evolucionista da literatura brasileira que achou seu ponto máximo de formulação na crítica de Antônio Candido, depois mergulhou-se no estudo hermenêutico da estrutura textual, levada ao seu nível mais elevado de rigor com Luiz Costa Lima, e, logo a seguir, a língua, a partir de uma perspectiva bakhtiniana, assume papel decisivo na produção das subjetividades contemporâneas, ganhando, no Brasil, importância nas análises textuais da crítica pós-estruturalista de maneira geral.

Esse manejo teórico da língua, nos textos críticos da literatura nacional, teve como consequência alguns paradigmas-base, para análise do texto literário: primeiro, esse texto deveria, acompanhando a evolução da língua, ser escrito nos mais altos níveis de desenvolvimento e correção gramatical, atendendo à norma culta da língua portuguesa (LP). Foram esses os critérios que validaram o prestígio de um Machado de Assis e de um Olavo Bilac, por exemplo. Em um segundo momento, a crítica mais ou menos circunscrita do Modernismo ao Concretismo norteia a análise textual a partir de uma noção estrutural da língua que migra para a teoria da literatura no conceito base de literariedade. Ou seja, o escritor devia criar, dentro do sistema fechado da língua, curtos-circuitos nos quais os significados fossem produzidos de formas inusitadas, causando um efeito de estranhamento no leitor. Em suma, tratava-se de afastar-se o quanto possível, do uso corriqueiro da língua. Foi o critério que celebrizou autores como Clarice Lispector e Oswald de Andrade ${ }^{1}$.

1 Obras como a Paixão segundo G.H. de Clarice Lispector e Memórias sentimentais de João Miramar, de Oswald de Andrade, ilustram bem nossa afirmação. 
Por último, é imputado ao escritor pós-moderno a politização da escrita no texto literário. A língua deixa de ser compreendida como meio de comunicação, complexo instrumental que punha em relação ideias e sujeitos, e passa a ser compreendida como sistema de representação, base semiótica de qualquer cultura. Não se tratava mais de pensar nas funções da linguagem, como propôs o linguista russo Roman Jakobson, mas de pensar como as estruturas linguísticas engendravam formas de produção do mundo. A partir dessa concepção passou-se à preocupação de como essas línguas hegemônicas e sua pretensa homogeneidade em contextos vernáculos, oprimiam outras possibilidades de expressão da existência.

Essa perspectiva compreende a língua, não mais a partir de Saussure, como um sistema homogêneo e fechado, mas como estrutura que é composta por um conjunto de variações e transformações. As concepções bakhtinianas encontram no meio do século XX as noções labovianas de variação linguística. Nesse contexto, a categoria deleuziana de literatura menor ganha impacto na crítica nacional à medida que permite estudar as reinvenções dessa língua oficial no corpus do texto literário, como uma forma de resistência política à dominação dos sistemas hegemônicos de representação.

Essa brevíssima genealogia, se assim podemos chamar, da relação entre língua e literatura na crítica brasileira tem uma continuidade indelével. Desde a crítica positivista e seu evolucionismo, passando pela hermenêutica estrutural e chegando a politização linguística pós-moderna, o que temos é uma compreensão da relação entre língua e literatura, e mesmo língua e cultura, baseada no grafocentrismo. A relação entre escrita e civilização marcam a modernidade ocidental, pois, a Europa capitaliza a tecnologia da escrita alfabética para afirmar, a partir dela, não apenas uma diferença em relação aos povos ágrafos, às culturas baseadas na oralidade, ou às que tinham forma diversa de grafia, mas para erigir a escrita alfabética como marca de superioridade cultural.

A escrita é uma das características centrais pelas quais o ocidente europeu irá embasar dois argumentos centrais utilizados para legitimar a colonização e o genocídio dos povos africanos e ameríndios, a saber; a) a exclusividade da experiência histórica, pois, se 
os povos não europeus não tinham escrita também não teriam história; b) um estágio avançado no percurso civilizatório. A esse respeito, é muito ilustrativo - da importância fundamental desses dois pilares para a justificativa ética e epistêmica da pretensa superioridade europeia - duas conhecidas passagens na filosofia ocidental: a que Hegel afirma que apenas a Europa possui história, e a que Heidegger afirma a superioridade da língua grega, sendo esta o logos fundante do próprio homem ${ }^{2}$. Dessa forma, a modernidade europeia incluía a Grécia no mapa de sua história e lhe imputava uma língua originária, fundando as bases do eurocentrismo, como regime epistêmico.

O critério da escrita como inegociável para a compreensão da história de um povo recortava o tempo reiniciando a narrativa do mundo a partir da modernidade, e definia um mapa quase exclusivamente europeu, para a ideia de civilização; enquanto isso, a língua grega era concebida a partir de um ideal de origem e pureza que influenciaria não só as línguas vernáculas, em suas pretensões esquizofrênicas de pureza, mas também, e sobretudo, deveria servir para semiotizar uma representação metafísica do mundo e do homem, calcadas na universalidade da razão ocidental.

Nesse arranjo, ficam relegadas a segundo plano, como inferiores e classificadas como expressões não-civilizadas, duas experiências poderosas na fabulação da existência do homem e das sociedades: a oralidade e a memória. É desnecessário chamarmos a atenção para o fato de mesmo a cultura grega ter sido produzida, a partir das narrativas orais e da memória popular grafadas na Ilíada e na Odisseia, por Homero. O fato é que a capitalização geopolítica da escrita permitiu à Europa o primeiro gesto industrial da humanidade, a reprodução em escala mundial, de uma ideia de história e de uma concepção de língua. Ambas sintetizam de maneira liminar o núcleo epistêmico do pensamento eurocêntrico e colonial: a universalidade da história e a pureza/unidade da língua, as duas fundamentando epistemologicamente a superioridade europeia, e municiando a hierarquização racial no

${ }^{2}$ Ver primeiro capítulo de Pensar Nagô, de Muniz Sodré. 
processo colonizador. Esse movimento demonstra que o epistemicídio é condição fundante do racismo moderno que vigora a partir da expansão colonial europeia.

Esse grafocentrismo protagoniza o pensamento ocidental desde o início da modernidade, legislando em diversas áreas do saber, sobre a validade ou não de uma série de conhecimentos. Nenhuma área das ciências humanas esteve apartada desse funcionamento, não há jurisprudência no ocidente que me pareça efetivamente relevante, mesmo as diversas aberturas à oralidade, como ferramenta de pesquisa e coleta de dados, a partir das revoluções epistêmicas no campo da historiografia europeia, com Escola dos Annales, Micro-história, história das ideias, nenhuma dessas perspectivas ousaram pensar a oralidade como base epistemológica de um outro saber, antes a utilizaram como instrumento e meio para afirmações que se inscrevem irremediavelmente dentro do eurocentrismo.

Não foi diferente no campo da teoria e, por conseguinte, da crítica literária no Brasil. Ambas foram, em sua grande maioria, eurocêntricas e, por consequência, racistas. É nessa perspectiva que podemos compreender a marginalização e o apagamento desferidos contra Lima Barreto, e sua literatura, como também, é a partir desses mesmos critérios que podemos entender as engrenagens discursivas e contraditórias de seu posterior festejo, na crítica nacional, a partir do final do século passado.

Alguns empreendimentos teóricos tem desferido um abalo contra a estrutura grafocentrica da crítica literária brasileira: a proposição do conceito de literatura terreiro, de Henrique Freitas (2016), o de oralitura, de Leda Maria Martins (1997), e literatura silenciosa, de Edmilson de Almeida Pereira (2010), todos chamando atenção para o protagonismo da oralidade num conjunto literário produzido pelas diversas manifestações da cultura negra, e mais especificamente, as voltadas ao universo cultural negro de matriz yorubana e bantu.

Estudando a Irmandade Negra do Rosário do Jatobá, Leda Martins, apresenta o conceito de oralitura. Relacionando performance com atos de fala, a autora formula uma teoria que conectando oralidade e corpo, anota a importância fundamental da oralidade nos reinados negros, e nos instrumentaliza na compreensão da produção oral das comunidades negras como "extensão dos rizomas que reterritorializam e transcriam as culturas africanas 
na cartografia brasileira” (1997, p 21). Já o conceito de Literatura Terreiro é proposto por Freitas, como conectado a uma "[...] ética e estética de textos produzidos desde o corpo negro permeado pela cosmogonia africana e negro-brasileira.” (2016, p. 266). O teórico chama atenção para as características da literatura terreiro, anotando que "Ele está conectado às epistemes que circulam nas religiões de matriz afro-brasileira e, prioritariamente, refere-se às produções oriundas destes espaços que se vinculam a uma dimensão não só oral, mas multimodal diaspórica. (2016, p. 266). Em “Cantos poemas: uma literatura silenciosa no Brasil”, Edmilson Pereira, defende a viabilidade em “considerar textos do Congado como corpus literário se levarmos em conta a organicidade da literatura oral e a existência de obras escritas que formam uma antologia representativa do tema" (2010, p. 571), mas logo em seguida o autor nos chama atenção para o fato de que "os cantopoemas tecidos com os fios dos mundos banto e católico não foram devidamente considerados como fonte de diálogo e inspiração para a formação do repertório poético brasileiro” (2010, p. 572). Nos três exemplos expostos notamos que o trabalho de produção de uma teoria descolonizada, no campo literário nacional, tem investido na discussão da oralidade como base epistemológica de um outro arcabouço teórico-metodológico para a compreensão de produções literárias não-canônicas.

Atento a esse movimento, propus em Contemporaneidades periféricas: anotações para alguns estudos de caso, a noção de transsemiose, apontando para o fato de que uma abertura do campo literário para as formas textuais produzidas na cultura negro-brasileira, dos orikis, provérbios e itáns às produções periféricas contemporâneas, é necessariamente uma abertura para tudo aquilo que ficou, na tradição ocidental, fora da teoria. Portanto, não se trata de um gesto de esgarçamento e atualização retórica, de invenção de novos procedimentos e técnicas investigativas que redundem o mesmo regime epistemológico da teoria, a saber: o eurocentrismo. É necessário olhar para o que esteve, durante todo esse tempo, a margem da teoria e da crítica: a oralidade.

Por isso, por transsemiose denominamos "os processos de aglutinação de linguagens e misturas semióticas que ocorrem entre os diversos saberes fora do campo disciplinar, ou 
entre esses e as disciplinas, mas nunca entre os campos disciplinares (SILVA, 2017, p. 48). Mas por transsemiose, chamamos, também, processos que ocorrem em duas dimensões: a) criativa; b) crítica. A dimensão criativa investe na oralidade como código primeiro de suas produções literárias, é o caso de boa parte da literatura periférica contemporânea e do rap, mas já era, no início do século passado, o procedimento escolhido por Lima Barreto, quando ele investe contra o arsenal de gramatiquices e erudição da língua escrita, produzindo uma minoração da língua hegemônica a partir de um procedimento criativo que remete a língua à informalidade e aos processos comunicativos da oralidade, e não à tradição literária que busca na norma culta seu código de referência.

Já a dimensão crítica se inscreve no que chamamos no texto já referido de "perspectivismo crítico", ela deve operar por transsemiose, porque implica, necessariamente, o extravasamento do campo disciplinar para a compreensão das gnoses referentes aos saberes não hegemônicos. Uma crítica que busca analisar os objetos literários não-canônicos a partir do mesmo repertório cultural e técnico disposto pela tradição das teorias da literatura, redunda no campo epistêmico a colonialidade do poder, negando a diferença e a multiplicidade das diversas epistemologias afro e indígenas, espoliadas pelo regime colonial. O que está em jogo nessas operações, nos dois âmbitos: crítico e criativo, não é opor duas formas de registro da língua, mas por em contato por "comunicação transcultural” (SODRÉ, 2017) regimes epistêmicos diferentes, o eurocêntrico e os negro-brasileiros, e isso só é possível a partir do transito entre os diversos sistemas semióticos que compõem a cultura brasileira.

Esse é o movimento de radical operado por Lima Barreto, e implica uma transsemiose porque põe em diálogo a tradição grafocentrica da literatura ocidental com seu recalcado, a oralidade. Duas semioses, posta em contato a partir de uma perspectiva transdisciplinar, já que relaciona as gnoses afro-brasileiras com os saberes inscritos no campo disciplinar da teoria da literatura, da historiografia e da crítica literária. Esse recurso ético-estético da literatura barretiana, punha em crise, de uma só vez, as noções de pureza e unidade, tão fundamentais aos projetos nacionalistas hegemônicos, e ainda produziu a partir da língua e na literatura, o processo de inclusão do negro brasileiro no enredo nacional. 


\section{Lima Barreto - a produção do devir negro na língua}

A crítica literária junto com a antropologia e a história interditaram os projetos contra-hegemônicos na literatura brasileira, vide o silêncio imposto a Luiz Gama, Maria Firmina dos Reis e Lima Barreto, durante grande parte do século XX. Assim, o gesto fundador da modernidade europeia, que relacionava universalidade e pureza protagonizou o imaginário colonial, assombrando a psique do colonizado e engrossando os projetos nacionais pré e pós-independência. Uma língua pura deveria narrar uma nação homogênea, eram basicamente esses os critérios que marcaram a solidificação de uma crítica da literatura entre nós, se estendendo diversificadamente de Machado de Assis a vertentes do modernismo. Portanto, numa equação relativamente simples, universalidade e pureza somadas produziam a civilização, e como consequência deveriam duplicar o eurocentrismo, no campo das ideias. $\mathrm{O}$ racismo era, pois, legitimado no campo da história e da antropologia, pelo evolucionismo, e no campo da linguagem, pelo grafocentrismo. Ou melhor, a escrita era a própria condição de possibilidade pela qual se afirmava ou não a "evolução" de um povo e a validade de seus saberes.

Quando Machado de Assis, ao fundar a Academia Brasileira de Letras, determina como uma de suas funções essências a produção de uma unidade linguística que auxiliaria no plano de construção da unidade nacional, e estabelece o que será a diferença fundamental que o separa de Lima Barreto. O autor de Bruzundangas não fez, senão, ao longo de sua literatura, afirmar a impossibilidade da unidade.

A discussão sobre a diferença entre Machado de Assis e Lima Barreto não deve, a nosso ver, ser buscada na mensuração entre maior ou menor adesão a uma luta antirracista, ambos autores são fundamentais para a compreensão da estrutura racista que rege a literatura brasileira. Machado foi, a seu modo, um homem que combateu o racismo que o circulava, e ironicamente é tido, por grande parte da crítica nacional, o ponto mais alto de realização estética e narrativa da prosa brasileira. Como rechaçar a importância disso num contexto em que o negro era produzido pelo discurso científico e cultural como inferior e menos capaz intelectualmente? Porém, esse quadro nos desafia a outra pergunta, bastante 
complexa, para explicar essa contradição em tese: um campo literário efetivamente racista, desmascarado por uma série de pesquisas ao longo dos últimos vinte anos, sendo a mais contundente delas a da professora Regina Dalcastagnè ${ }^{3}$, na qual a porcentagem de escritores e personagens negrxs é assustadoramente inferior aos brancos mesmo no século XXI - como esse campo de saber pode eleger como seu cânone um autor negro?

As respostas mais simples versam sobre a hipótese que, de antemão, refutamos, ou seja, o fato de Machado ter virado cânone na literatura brasileira não se deve ao fato dele ter escondido sua negritude, isso é impossível na própria estrutura fenotípica do racismo brasileiro. Beatriz Rezende, em seu livro Lima Barreto e o Rio de Janeiro em fragmentos, levanta algumas possibilidades de distinção entre Machado e Lima, que nos dão pistas para compreender a diferença com que ambos, sendo grandes escritores, foram tratados pela crítica. Dentre elas, destaco duas: a ideia de que tanto o autor de Dom Casmurro quanto o autor de Clara dos Anjos tinham conhecimento das "camadas subalternas da população", mas que Machado escolheu permanecer, desse grupo social, um observador distanciado, justamente o contrário do que fez Lima Barreto; a outra seria a leitura de que Machado, a partir de seu ceticismo e de uma compreensão profunda de seu próprio tempo, desistira do diálogo com o leitor.

As duas possibilidades levantadas por Beatriz Rezende apontam para uma questão central: a distância entre Machado de Assis e o público. O autor era um homem além de seu tempo, e, consciente disso, preferiu afastar-se tanto dos subalternizados quanto da pequena burguesia que compunha aquela época - a classe leitora no Brasil. Afastar-se do público subalternizado era justamente o oposto do que pretendia a literatura barretiana, como deixou claro o autor, em seu texto O destino da Literatura.

Os dispositivos discursivos que operaram esteticamente o afastamento de Machado e seu público são: a escolha pela realização do padrão culto da língua portuguesa e o elenco

${ }^{33}$ A pesquisa referida encontra-se discutida no livro, Literatura brasileira contemporânea: um território contestado. 
de personagens e dramas burgueses, ou seja, a história contada a partir de uma perspectiva superior. O que vai duplicado no gesto do escritor de Memórias Póstumas de Brás Cubas é a universalidade da experiência do grupo dominante, europeu, no caso colonos emergentes e a burguesia carioca, branca e aportuguesada, e com essa escolha, a priorização do registro escrito e culto da língua.

O que está posto nesse brevíssimo quadro comparativo é que, na questão central que atravessou toda a literatura brasileira até o modernismo - o problema da dependência cultural -, Machado e Lima Barreto foram buscar, em lugares discursivos totalmente opostos, o repertório para a produção das identidades que compunham o quadro sócio-histórico da nação. A concepção de língua, posta em jogo nas narrativas barretianas, não propunham, em nenhuma instância, senão por meio da ironia, do riso, como em Policarpo Quaresma, a ideia de uma unidade linguística, ou de uma pureza original do idioma. E essa diferença é, a nosso ver, o fundamento da distinção entre um e outro escritor.

Quando Lima Barreto opta por não aderir à perspectiva literária vigente, ele não está apenas negando se inserir numa tradição que se formava em torno do campo literário brasileiro, e que tinha e teria em Machado seu ponto de referência, ele está num duplo gesto, se colocando fora da tradição que então se formulava, e propondo outra perspectiva crítica e teórica para a literatura brasileira. Esse procedimento era proposto em Barreto, por dois processos base: a) seu ponto de vista narrativo não era o hegemônico. Não se trata apenas de incluir em seus textos, personagens das classes pobres da população brasileira, mas de narrar a partir desse lugar, ou seja, narrar a partir de um território e de uma experiência corporal negada pelo projeto hegemônico de modernidade. No caso de Lima Barreto, esse corpo era negro e esse território periférico; b) em oposição ao grafocentrismo que subsidiava uma ideia de homogeneidade no binômio língua-identidade, o autor de Diário do Hospício buscou estruturar sua literatura a partir da oralidade, trazendo para sua literatura, em pleno século XX, uma concepção de língua distante do campo literário. 
Ambos os mecanismos da engenharia textual barretiana apontam para a produção de uma diferença colonial na literatura brasileira, pois a escolha do autor de sair da formação discursiva que começava a erigir a tradição das letras nacionais é um procedimento radical à medida que traz para o campo literário recursos técnicos e teóricos avessos ao eurocentrismo, portanto, inscritos numa outra proposta epistemológica que não a europeia. Esse procedimento esparramado por toda a produção teórica, crítica e literária de Lima Barreto é radical, no sentido em que, a partir de uma perspectiva negra, ataca o problema da dependência cultural no núcleo discursivo de sua formulação, a epistemologia.

\section{A língua no jogo da descolonização}

Quando Gregory Petrovich Bogoloff desembarca no porto do Rio de Janeiro, o "Homem da polícia marítima” pede que ele se identifique. A partir desse momento, há uma grande confusão, o intérprete fala lituano e acha que é russo, Bogoloff, bacharel em línguas orientais, não fala português nem lituano, e arrisca um francês, enquanto o policial não fala nenhuma dessas línguas, e são todos socorridos por um transeunte que falava francês e traduz para o policial e o intérprete as respostas do personagem. Nessa minibabel, Bogollof percebendo que o policial podia não lhe deixar desembarcar, saca seus "papéis": o passaporte, uma carta da imigração e o diploma universitário.

Entre a documentação de Bogoloff, o agente "esteve a examinar" a carta da Universidade de Kazan, “com o respeito que merecia um pergaminho” e de repente pergunta ao emigrante: - “Que língua é esta em que está escrita?”, ao que o personagem barretiano responde em francês-latim. O policial não entende. E Bogollof com espanto encerra o episódio constatando a estranheza de um falante de uma língua neolatina não reconhecer sequer uma palavra de sua língua matriz.

O episódio acontece logo no início do romance Aventuras do dr. Bogoloff, e se insere numa rede de episódios iniciais nos quais a polícia aparece como instituição controladora da vida dos cidadãos mais pobres, sendo a polícia russa, de forma mais ou menos indireta, a responsável pela migração do professor para o Brasil. O enredo demostra, numa análise 
mais direta, como a ideia de "pátria" funciona a partir do patrulhamento, da violência e do cerceamento do indivíduo.

Iremos propor outro recorte no rizoma que se abre, a partir dessa cena, no romance barretiano. O espanto de Bogoloff quanto ao completo desconhecimento do policial em relação ao latim, ao ponto extremo do personagem não reconhecer a própria palavra "latim", opera um dado caro na obra barretiana, o esfacelamento da ideia de origem ${ }^{4}$. Essa distância, apontada por Bogoloff entre o latim e o português falado pelo agente da lei, aponta para um processo intensivo de rasuras, ranhuras e fraturas na diacronia da língua portuguesa no Brasil.

O fato de o agente não conseguir reconhecer sequer uma palavra em latim indica que o processo de evolução esperado pelo bacharel em línguas orientais não tinha ocorrido em solo nacional. A língua não tinha seguido seu percurso diacrônico linear e conciso, mantendo a estrutura homogênea de sua realização, antes a língua tinha variado e mudado tanto, e apresentava uma variedade sincrônica tão ampla ao ponto de perder a relação com sua possível origem etimológica.

É ilustrativo dessa distância, entre as realizações do português no Brasil, o episódio narrado por Maestri e Carboni, no qual Domingos Jorge Velho, paulista e integrante das forças colonizadoras, por volta de 1695, expressava-se mais à vontade na língua geral, "fazendo-se sempre acompanhar de intérprete, quando devia entrar em contato com as autoridades administrativas coloniais lusitanas" (2012, p. 27).

No hiato entre o latim e o português falado pelo policial, o que está em jogo são outras possibilidades de reconhecimento e outros sistemas linguísticos de representação. Barreto está dizendo, no silêncio de sua elipse, que o português como uma língua homogênea não existe no Brasil, e que sua realização é tão desfigurada ao ponto de não ter mais ligação com sua origem, a língua, diferente de si mesma, não podia mais ser restaurada em

\footnotetext{
${ }^{4}$ Discussão empreendida no texto: Da semelhança à similitude: Policarpo Quaresma e a rasura da Origem e da pureza na literatura brasileira. In Encruzamento literários e culturais / Organização de Jancleide Góes; Lívia Sousa; Verônica Cerqueira. Salvador: Editora Segundo Selo, 2017.
} 
sua pretensa grandeza vernacular por nenhuma diacronia evolucionista - estava, pois, em pleno devir.

Essa pequena cena apenas ilustra uma marca decisiva em sua literatura, a língua não estava nunca ligada ao resgate da grandiosidade de uma realização original da literatura, da nação ou da identidade, pretendida pelas correntes críticas vinculadas ao evolucionismo histórico, que marcaram a primeira fase da crítica literária nacional. Assim, Barreto se opunha de forma incisiva ao paradigma machadiano que norteava o campo das letras nacionais. Esse gesto foi de uma potência de impossível reconhecimento para a crítica contemporânea ao autor, pois, se como queria Machado de Assis, a unidade linguística era corolário da unidade nacional, em uma só tacada, afirmando a diferença na língua, Barreto afirmava a diferença na nação e na identidade.

A informação sobre o caráter diverso e múltiplo da língua portuguesa, expressa em elipse na cena descrita acima, não constitui caso isolado na obra barretiana. Antes ela redunda uma questão central na prosa do escritor, os usos comuns da língua compõem a matéria-prima do texto barretiano, em detrimento do modelo ideal e abstrato da língua, inscrito como norma culta. Essa escolha e suas consequências inscrevem a produção do autor de Cemitério dos Vivos numa formação discursiva diametralmente oposta ao que se acatava na época como literário.

É demais conhecida a posição teórica de Lima Barreto quanto ao formalismo literário. Ferrenho opositor das "belas letras", exprimiu em diversos textos, como na abertura da revista Floreal, em "O destino da Literatura" e "Amplius", a ideia de que a literatura deveria ter uma proposta ético-estética comprometida com o povo, propondo-lhes um projeto de solidariedade e humanidade, que só poderia ser posto em prática a partir da instauração de um circuito comunicativo entre os diversos grupos, sujeitos, classes e raças que compunham a sociedade. Para a instauração desse circuito interacional, a linguagem utilizada deveria comunicar diretamente à sensibilidade popular, e não recorrer aos arrebescos e adornos que caracterizavam as letras nacionais no Brasil república. 
Essa proposição barretiana, espraiada em seus textos críticos e crônicas, aparece diversas vezes em seus romances, sendo uma delas, nas palavras de Mascarenhas, personagem principal de Cemitério dos Vivos, quando ele narra sua "produção de si" como escritor. Mascarenhas, influenciado por Dona Efigênia, com quem se casaria mais tarde, começa a ler livros não clássicos e deixa "aquela falsa e tola atitude positivista de só falar em Shakespeare, Dante e Molière" (BARRETO, 2004. p. 135). A consequência das novas leituras foi tomar coragem para lançar-se à escrita, o que segundo o personagem teria grande influência sobre sua existência.

O episódio ilustra sem ressalvas uma crítica à ideia de cânone como paradigma de fixação do que deve ser ou não compreendido como literatura, como também nos propõe pensar como essa concepção de alta literatura cria um fosso que separa leitor popular e texto literário. Todo o projeto ético-estético da literatura barretiana é atravessado pela superação desse espaço, dessa distância, que culmina por esvaziar, em sua concepção, a própria ideia de literatura.

Os desdobramentos discursivos dessa concepção canônica do literário nas letras brasileiras, no início do século XX, eram perversos, pois agenciavam todo o processo de invisibilização do povo negro e pobre do Brasil colônia, como personagens e produtores dos textos literários, como cidadãos e sujeitos históricos, à medida que os tidos "grandes" textos tinham como critérios absolutos expressar signos e valores das classes dominantes. Por isso, enquanto a língua culta, como critério de qualidade do texto literário, com sua capa de neutralidade e transparência, dissimulava a ideologia da elite colonial e republicana por trás dos clássicos, os temas e tramas narrativos apagavam da história nacional os personagens subalternizados pelos grupos dominantes, brancos, senhores feudais e colonos ricos.

Esses movimentos de neutralização da linguagem literária e narração da experiência das classes dominantes operam no campo das letras a função de apaziguar as tensões raciais e sociais que povoavam a recém-fundada república. Mas operam um efeito ainda mais escroto: como estava a cargo da literatura e da história narrarem os discursos fundacionais, 
esses apagamentos construíam, seguindo a vontade de verdade da aristocracia branca, um projeto de nação que excluía os negros e indígenas do processo de cidadanização, pilhando os signos das culturas afro e indígenas para uma representação subalternizada e estereotipada de seus sujeitos, ou apenas relegando suas produções culturais e simbólicas à sombra e ao silenciamento.

\section{Lambendo a língua do povo preto}

Escrever a partir de um registro informal da língua foi, portanto, um dos modos pelo qual Lima Barreto enfrentou a engenharia discursiva desse apagamento. A opção pela variante popular da LP, como matéria prima do texto literário tem efeitos potentes de devastação da colonialidade do poder/saber. O primeiro e mais evidente é a historicização da língua e, por consequência, do conjunto de relações sócio-históricas que ela apresenta. Desnaturalizar o uso da língua, àquela altura, era decisivo para deslegitimação de toda uma rede de relações e hierarquias que compunha o quadro social.

Afirmar que registros populares da língua, utilizados pelo povo mais pobre e humilde dos subúrbios cariocas, trazendo um grande repertório da cultura negro-brasileira, carregando "rastros" da cultura indígena, poderia servir como ferramenta para narrar a nação e fundar o senso de pertencimento de forma democrática, era pensar a nação a partir da diferença, e isso não poderia ser permitido pela crítica aristocrática e branca, que colonizava a intelectualidade brasileira. O que estava em jogo era um projeto popular de nação em oposição a um projeto colonial de poder.

O segundo diz respeito aos projetos de nação modernos que, como nos informaram Etiene Balibar (1990), Benedict Anderson (2008), Homi Bhabha (2002), Hobsbawm (1990), Stuart Hall (2006), inventam como núcleo de sua comunidade imaginada, ou seja, Estado-nação moderno, uma etnicidade fictícia que precisa produzir o "efeito de unidade" para que o senso de pertencimento coletivo ponha em funcionamento sua função integradora, e as diferenças possam harmonizar-se num processo supostamente dialético que funda a cultura nacional. 
O que põe em funcionamento toda essa engrenagem cinematográfica, essa teatralização da unidade, é a língua nacional. Por isso, quando Lima Barreto ataca a ideia da língua como unidade, ele está pondo em suspenso todo o discurso falacioso, perverso e pervertido da homogeneidade, que não guarda, senão, o desejo narcísico das classes dominantes de duplicar-se indefinidamente, na história e no poder. Só que, para isso, é necessário que não haja, nem um nem outro, que ambos, poder e história, estejam dissolvidos numa linguagem que, natural, não faz senão espelhar a própria natureza do real.

No contexto brasileiro em que Lima Barreto estava inserido, o que se narrava como natural era a superioridade do homem branco sobre o negro, e como consequência a massacrante diferença de classe entre uns e outros. É por isso que a desmontagem da colonialidade do saber, operada na literatura do autor, é seguida e contígua a um combate feroz e incansável ao racismo e às correntes teóricas que o alicerçam, no caso, o positivismo. As críticas a corrente de Augusto Comte são largamente espalhadas pela sua obra romanesca e circula da boca de um para outro personagem.

Em uma conversa imaginária, Gonzaga de Sá, de Vida e Morte de M. J. Gonzaga de Sá, diria a ao narrador de Policarpo Quaresma: "Se no século XVII, o que separava os homens por raças várias era o discurso religioso, há de ser o científico que as separará daqui a tempos", ao que este lhe responderia que são "os adeptos desse nefasto e hipócrita positivismo, um pedantismo limitado e estreito, que justificava todas as violências, todos os assassínios, todas as ferocidades em nome da manutenção da ordem, condição necessária, lá diz ele, ao progresso". Um pouco mais revoltado, Mascarenhas de O cemitério dos vivos, contaria aos dois o caso do advogado que pedia a condenação de um réu apontando os crimes passados de seu pai, enquanto o povo e a ciência moderna repetiam "tal pai, tal filho". Os três de certo olhar-se-iam meio desolados, descrentes no progresso, na ciência, na modernidade, e, de repente, Policarpo, como se lhes contasse um segredo, narraria o dia em que Chica, a velha cafusa, "esquelética Medéia", tirou com um feitiço todos os bichos de sua plantação, o que ele não havia conseguido fazer com as mais altas tecnologias científicas. 
O terceiro, e quiçá, mais potente efeito do uso de variantes do português, na literatura barretiana, diz respeito à produção de locus de subjetivação para os homens e mulheres negrxs e periféricos. Pois, como assinala Florence Carbonni e Mario Maestri, em A linguagem escravizada, "reprimindo as formas de expressão das classes subalternizadas, reprime-se suas formações discursivas e, portanto, sua visão de mundo”. (2012, p 109). Suprimir do outro a possibilidade de expressar-se em sua língua é impedi-lo de viver os signos de sua cultura, ou seja, de reconhecer-se enquanto sujeito, no exercício diário e contínuo de significar-se. É nesse sentido que devemos compreender por que a separação dos africanos escravizados obedecia ao critério de impedir que sujeitos que falassem as mesmas línguas habitassem os mesmos espaços geográficos.

É conhecida, a esse respeito, a explicação dada por diversos linguistas e estudiosos da questão racial no Brasil. Todos apontam o fato de que os africanos capturados e trazidos para o trabalho forçado na colônia portuguesa pertenciam a diversas etnias, nações e territórios africanos, e por consequência falavam idiomas distintos; fon, irorubá e banto, entre outros. A separação dos negros escravizados, a partir do critério do idioma, visava dificultar a organização de rebeliões, motins e fugas. Essa afirmação bastante conhecida e incontestável tinha efeito imediato e perdia com o passar do tempo sua inteira vitalidade.

Mas outro efeito daninho dessa estratégia colonial era que, rompendo o elo entre sujeito e linguagem, o sistema colonial visava interditar o processo de subjetivação dos negros e negras nascidos no Brasil, com o repertório cultural das nações em que descendiam em África. Com essa interdição lhes sobraria apenas significar-se como sujeito já imersos na semiose colonial, reconhecendo-se, desde e para sempre, a partir da língua colonizadora, como escravos, ou seja, tendo suprimida a sua possibilidade de produção de si, como indivíduo e sujeito.

Essa estratégia perversa ignorava, do alto da soberba colonial, primeiro, a poliglosia dos povos africanos que comumente falavam diversas línguas e tinham uma facilidade tremenda para o aprendizado de línguas; segundo, subestimaram a absurda capacidade de invenção e combate do povo negro africano que, a partir da analogia, sincretiza orixás e 
santos católicos, podendo, assim, em plena escravidão, pôr em funcionamento os signos e sentidos da cultura africana. "Já se evidenciava aí a estratégia africana de jogar com as ambiguidades do sistema, de agir nos interstícios da ordem ideológica vigente" (SODRÉ; 2005, p. 124).

Porém, no contexto da colonização, como nos mostra Maestri e Carboni (2012), havia uma multiplicidade de línguas circulando oficiosamente no cotidiano. Nos primeiros dois séculos da colonização, a língua geral, formada entre os diversos falares indígenas e a LP, protagonizava a comunicação oral na colônia. Com a chegada de cerca de cinco milhões de africanos forçados a emigrar para o Brasil, trazendo junto com a mão de obra escravizada pela coroa portuguesa um número estimado de trezentas línguas africanas, que passaram a integrar o processo sincrético com a LP, foi produzindo um conjuntos de línguas gerais "regionalizadas" como "o nagô/yoruba na Bahia; o 'mina” na área da mineração e o 'quimbundo/congolês' no Norte, na Bahia e no Sul, funcionava, como principais falares línguas gerais - das comunidades africanas e afrodescendentes” (2012, p. 23).

Referindo-se ao campo religioso, mas com certeza como metonímia de todo um mecanismo de reposição da ordem simbólica africana, no Brasil, Muniz Sodré nos informa em $A$ verdade Sedurida que "a ordem original (africana) foi reposta, sofrendo alterações em função das relações entre negros e brancos, entre mito e religião, mas também, entre negros e mulatos e negros de umas etnias com os de outras" (2005, p 132). Esse processo de reposição da ordem africana em solo nacional encontra na língua um campo potente, e essa relação sincrética entre as línguas de matriz africana e a LP não apenas instaura mais uma variante, muito além disso, ela põe em funcionamento um novo sistema de representação, à medida que transforma completamente o que viria a ser a língua portuguesa, na colônia, "engendrando possibilidades novas de relacionamento com o real", no seio da cultura colonizadora.

Porém, já na metade do século XVIII, com Marques de Pombal decretando o português como única língua da colônia; os projetos românticos de afirmação de uma nacionalidade; a posterior proclamação da independência e a necessidade de afirmação de uma 
unidade nacional - tudo isso intensificou o processo de opressão contra a cultura negrobrasileira. Se os projetos de nação, legislados pelas teorias raciais do século XIX, afirmavam os negros e mestiços como grande motivo do atraso nacional diante da civilização europeia, a língua portuguesa cumpria uma dupla função: vincular a ex-colônia ao repertório cultural europeu, e apagar as contribuições afro e indígenas para a produção da narrativa nacional.

É justamente nesse contexto da definição do nacional que grafocentrismo, norma culta e unidade linguística duplicam o eurocentrismo das teorias raciais e por meio do epistemicídio põe em funcionamento o racismo como máquina de morte da alteridade na cultura nacional. Junto com as línguas africanas, a oralidade e a memória deviam ser interditadas como modo de relacionamento com o real. A escrita da história se encontrava contígua a uma história como violência: física e epistêmica.

Dessa maneira, acirrada perseguição e apagamento da presença negra na cultura nacional, algumas línguas africanas, e suas variantes, garantem sua sobrevivência como código de mediação dos rituais litúrgicos das comunidades-terreiros (SODRÉ, 2005). Excluídas do repertório linguístico nacional e, por conseguinte, dos projetos narrativos da nacionalidade, a influência do negro para a produção da vida nacional era escamoteada, pilhada e dissimulada pela colonialidade do saber.

Quando Lima Barreto escolhe o registro informal da língua, trazendo a memória, a diversidade e a oralidade como signos de sua escrita, ele está combatendo esse apagamento, racializando a língua, exibindo sua fratura de classe - espelhando sua multiplicidade sincrônica, ele revitaliza o repertório negro-brasileiro no centro da língua hegemônica e colonial.

Nesse contexto, é fundamental compreender que a negativa em utilizar uma língua idealizada e abstrata nas suas obras literárias confronta o triângulo eurocêntrico do fechamento da língua no projeto de nação: grafocentrismo, norma culta e unidade são negados pela escrita barretiana, de modo que sua recusa se constitui de modo inegável e veemente numa crítica à própria modernidade, tal qual ela se impôs, no Brasil, pela força da elite branca colonizadora. 


\section{Encaminhamentos finais: o xadrez da oralidade - Lima Barreto e o modernismo}

O uso do registro informal da língua, pode ser lido como uma tentativa de validar o repertório oral da cultura negro-brasileira enquanto recurso estético e epistêmico no campo da literatura nacional. Essa conduta também inscreve a produção barretiana em uma proposição ética, pois a oralidade traduz no campo formal as preocupações éticas que atravessam toda a obra barretiana, das crônicas aos romances: comunicar-se com o povo; promover a cidadania negra; e visibilizar uma produção epistêmica da cultura negro-brasileira, a partir da oralidade.

Carregar para o campo literário, com toda sua áurea de distinção e erudição, um conjunto de personagens, territórios e saberes, subalternizados na narrativa nacional, a partir da língua que circula nessas margens sociais, foi, em certa medida, cidadanizá-los. Dar à oralidade/a língua informal o status de literatura foi a engenharia discursiva da produção da cidadania negra, negada e vilipendiada, no início dos novecentos. Pareceu nítido para Lima Barreto que o projeto de cidadania do negro brasileiro não poderia se concretizar dentro do projeto de nação que se desenhava, na literatura nacional. Por isso, a unidade linguística e o grafocentrismo foram alvo de Lima Barreto em seu projeto estético e teórico, pois, na ânsia de suas representações homogêneas da literatura e da língua, produziam uma nação excludente e racista. É seguindo essa linha discursiva que temos insistido, ao longo do texto, que as escolhas do autor são inseparavelmente ético-estéticas.

Nesse sentido, como aponta Zélia Nolasco, não fazem sentido as críticas recebidas por ele ao longo do século passado, quando classificavam seus textos de descuidados e mal escritos. Para a crítica, "o maior pecado de Lima Barreto: ousar com a linguagem inovadora" (2011, p. 26). Essa constatação nos direciona novamente para a questão modernista, que rodeia, na sombra do silêncio, todo esse texto, pois esse mesmo "descuido com a linguagem", que tanto contrariou críticos como José Verissimo, foi amplamente festejado no modernismo paulista sob a alcunha de "linguagem coloquial". 
Em "A pedra mágica do discurso", de Eneida Maria de Souza, podemos ler sobre o Macunaíma de Mario de Andrade, obra seminal do modernismo brasileiro, a seguinte afirmação: "O grande mérito do livro reside na subversão e reconstituição do material linguístico e na recuperação da 'fala nova' brasileira, destituída de artefatos retóricos e gramatiquices portuguesas" (1999, p 42). Já em Poesia, mito e bistória no Modernismo brasileiro, Vera Lúcia de Oliveira, analisando a produção literária de Oswald de Andrade, aponta o caráter revolucionário do seu uso da língua: "O poeta realiza uma batalha contra a linguagem eloquente, retórica e ornamental, ainda vigente nas primeiras décadas do século[...]” (2002, p. 106). Esses trechos destacados poderiam ser colados sem nenhum adendo a qualquer investimento crítico feito aos livros de Lima Barreto que antecedem, em cerca de uma década, algumas das principais produções modernistas.

Os dois principais nomes do modernismo de 22, contemporâneos e conhecedores de Lima Barreto e sua obra, tiveram seus textos festejados pela crítica, a partir do elogio dos mesmos fatores que eram duramente criticados nos romances barretianos. O racismo flagrante neste episódio da literatura nacional denuncia e releva, por metonímia, as estratégias discursivas de produção do epistemicídio nas letras tupiniquins. Para compreender um pouco mais dessa engrenagem, podemos comparar, brevemente, as bases que fundamentam a aparição da oralidade na obra dos autores considerados modernistas às de Barreto.

É demais conhecida a influência que as vanguardas europeias tiveram sobre o modernismo brasileiro, entre negação e festejo toda a narrativa paulista sobre o movimento inventaria uma série de contribuições para a reformulação das letras nacionais, vindas das "revoluções estéticas europeias", entre elas a de maior impacto foi a quebra do verso, e as inversões sintáticas que, retirando o poema das formas fixas e asfixiadas da tradição parnasiana, levariam a produção literária do Brasil a aproximar-se da coloquialidade e da linguagem popular. Portanto, as aparições da oralidade nos textos modernistas, sobretudo, da primeira fase, remontavam ao diálogo dos autores com as revoluções formais das vanguardas europeias. O que estava em jogo era atualizar a produção nacional, dialogando com o que de mais novo existia na literatura mundial. É nessa chave que devemos ler tanto as 
pesquisas populares no Macunaíma quanto os sotaques populares que atravessam Pau-Brasil, de Oswald de Andrade.

Em Oswald de Andrade, de forma radical, a busca dessa linguagem popular se solidifica como recurso meramente estetizante, não marca uma ruptura epistêmica, nem propõe uma tensão entre as variantes linguísticas existentes e os sujeitos de fala, figuram, no máximo, como mero adorno ilustrativo da diversidade nacional. Embora Oswald tenha o mérito inegável de visibilizar os sujeitos dessas falas, o faz a partir da distância inviolável para um homem pertencente à aristocracia branca paulista. O Macunaíma esboça um mergulho num Brasil profundo (ideia que tanto fascinou os modernistas), comprometido em espelhar na língua a diversidade sociocultural da nação. A busca da diferença exótica e distante, empreendida pelo herói sem nenhum caráter, denuncia a continuidade do recalcado, mesmo no projeto modernista. As variações populares da língua ganham espaço quando remetem ao plano fantástico da rapsódia, as variantes populares apareciam vinculadas ao imaginário mito-poético que tanto estereotiparam as presenças negras e indígenas no Brasil.

Em nenhuma das duas obras, Pau-Brasil e Macunaíma, encontramos aspectos decisivos do uso da oralidade que são centrais em Lima Barreto: a) seu caráter ético-estético, de produção de uma cidadania via língua e literatura, para o povo subalternizado; b) a compreensão de que a oralidade, que circulava nos espaços comunicativos das classes populares, trazia um repertório cultural e simbólico central para a constituição do Brasil enquanto nação autônoma. Por isso, a afirmação de Beatriz Rezende, de que "na crônica, como no romance e no conto, Lima Barreto, sem ser ainda o que depois de 22, será chamado de modernista, já provocava rupturas com uma linguagem que até aí precisava se apresentar acadêmica e erudita para tratar das coisas públicas” (2016, p. 72), é indiscutivelmente correta, mas incompleta. Pois, enfatizamos, em Barreto a oralidade cumpre seu papel de ruptura estética com os modelos canônicos, mas também a função ética de disputar a literatura e a narração da nação para produzir uma cidadania negra. Em suma, a oralidade em Lima Barreto remete, predominantemente, ao repertório cultural afro-brasileiro. 
Essas constatações não nos permitem mais considerar como doravante fizeram, e ainda fazem, alguns seguimentos da crítica brasileira, "a negação do ornamental” como recusa do literário. Rezende, falando das crônicas de Lima Barreto, faz uma ressalva na qual aponta que o autor "recusa o ornamental mas não deixa de assumir peculiaridades que fornecem estilo, pela introdução de elementos ficcionais e recursos narrativos” (2016, p. 84). Para nós, a radicalidade da produção barretiana é justamente que o abandono do ornamental é a produção de um outro estilo, portanto, não se trata em nenhuma dimensão da recusa do literário, mas justamente o contrário, de sua criação, de sua potencialização, de seu alargamento. Por que a literatura, diz a própria teoria, é experimentação de linguagem, proposição de formas e estetização da experiência.

A negação do ornamental, na proposta estética de Lima Barreto, tem a função de filtrar a comunicação com seu público, limpá-la dos adereços da tradição e da língua colonizadora, e deixá-la pronta, não apenas para espelhar um real, no sentido clássico da teoria, não se trata de produzir uma mimese, nem de se inscrever no realismo que o antecedeu, mas de comunicar um fato social e histórico, de dizer uma verdade, de espalhá-la por toda uma comunidade, de compartilhar uma experiência, ou melhor, recuperando Hampaté Bâ (2010), trata-se de dar um testemunho. Impor à palavra um compromisso ético de dizer sobre um lugar, seus sujeitos e seu tempo, a partir de sua experiência individual e coletiva.

\section{EL DEVENIR NEGRO EN LA LITERATURA BRASILEÑA: NOTAS SOBRE LA ORALIDAD EN LIMA BARRETO}

RESUMEN: En este texto buscamos trazar un breve panorama de la tradición eurocéntrica de las teorías de la literatura, y de la crítica literaria, en Brasil, resaltando el aspecto central de su formulación discursiva: el grafocentrismo. Tendremos que mostrar con las diversas concepciones de crítica literaria que circularon en el campo de las letras brasileñas eran grafocentricas, operando a partir de concepciones de lengua que no potencian la aprehensión del repertorio cultural negro, en la cultura brasileña. A partir de ese escenario expondremos cómo la escritura de Lima Barreto rasca ese engranaje discursivo en la literatura brasileña, operando un devenir negro en el lenguaje literario nacional, a través del uso del registro informal de la lengua en el texto literario. Esta operación barretiana, no produce una estetización de la oralidad, pero propone comprenderla como base epistemológica de una cultura negro-brasileña.

PALABRAS CLAVE: Literatura negra; oralidad; el grafocentrismo, Lima Barreto. 


\section{REFERÊNCIAS}

ANDERSON, Benedict. Comunidades imaginadas. São Paulo: Companhia das Letras, 2008

ANDRADE, Mario de. Macunaima. 19. ed. Belo Horizonte: Itatiaia Limitada, 1981.

ANDRADE, Oswald de. Pau-Brasil. 5. ed. São Paulo: Globo, 2000.

BALIBAR, Étienne; WALLERSTEIN, Immanuel. (1990). Races, nations, classes, les identités ambigües. Paris: La Découverte.

BARRETO, Lima. Cemitério dos Vivos. São Paulo: Planeta do Brasil, 2004.

BARRETO, Lima. Obra reunida. V.1. Rio de Janeiro: Nova Fronteira, 2018.

BARRETO, Lima. Obra reunida. V.3. Rio de Janeiro: Nova Fronteira, 2018.

BHABHA, Homi K. O local da cultura. Belo Horizonte: Ed. UFMG, 1998.

CANDIDO, Antonio. Literatura e sociedade. 8. ed. São Paulo: TA Queiroz editor, 2002.

CARBONI, Florence e MAESTRI, Mário. A linguagem escravizada. 3. ed. São Paulo: Expressão Popular, 2012.

DELEUSE, Gilles e GUATTARI, Félix. Kafka para uma literatura menor. Lisboa: Assírio \& Alvim,2003.

FREITAS, Henrique. O arco e a Arkhé. Ensaios sobre literatura e cultura. Salvador: Ogum’s Toques Negros, 2016.

HALL, Stuart. Identidade cultural na pós-modernidade. 11. ed. Rio de Janeiro: DP\&A, 2006.

HAMPATÉ BÂ, Amadou. Tradição viva. In: ZERBO, J.K (org.). História geral da África I. Brasília: MEC; Unesco, 2010.

HOBSBAWN, Eric. Nações e nacionalismos. Rio de Janeiro: Paz e Terra, 1990

MARTINS, Leda Maria. Afrografias da memória. Belo Horizonte: Mazza edições, 1997)

NOLASCO-FREIRE, Zélia. Lima Barreto e a literatura comparada. Jundiai/SP: Paco editorial, 2011.

NOLASCO-FREIRE, Zélia. Lima Barreto: imagem e linguagem. São Paulo: Annablume, 2005 .

OLIVEIRA, Eduardo. Cosmovisão africana no Brasil. Curitiba: Editora Gráfica Popular, 2006.

OLIVEIRA, Vera Lúcia. Poesia, mito e história no modernismo brasileiro. São Paulo: UNESP, 2001 . 
PEREIRA, Edimilson de Almeida. Cantopoemas: uma literatura silenciosa no Brasil. In: . (org). Um tigre na floresta dos signos. Belo Horizonte: MAzza, 2010.

QUIJANO, Anibal. Colonialidade do poder. In: LANDER, Edgardo (org). Colonialidade do Saber. Buenos Aires: Clacso, 2005.

RESENDE, Beatriz. Lima Barreto e o Rio de Janeiro em fragmentos. 2. ed. Belo Horizonte: Autêntica, 2016.

SANTIAGO, Silviano. Uma ferroada no peito do pé. In: Vale quanto pesa. Rio de Janeiro: Paz e Terra, 1983.

SILVA, Jorge Augusto de Jesus. Contemporaneidades periférica: anotações para alguns estudos de caso. In: - (org.) Contemporaneidades periféricas. Salvador: Editora Segundo Selo, 2018.

SODRÉ, Muniz. A verdade seduzida. Rio de Janeiro: DP\&A, 2005.

SODRÉ, Muniz. Pensar nagô. Petrópolis. Rio de Janeiro: Vozes, 2017

SOUZA, Eneida Maria de. A pedra mágica do discurso. Belo Horizonte: UFMG, 1999.

Recebido em: 21/06/2018.

Aprovado em: 20/12/2018. 